\title{
Mitigating Environmental Sustainability Challenges and Enhancing Health in Urban Communities: The Multi-functionality of Green Infrastructure
}

\author{
* Dr. Adedotun Ayodele Dipeolu 1 (D) , Dr. Onoja Matthew Akpa 2 (iD) and Prof. Joseph Akinlabi \\ Fadamiro ${ }^{3}$ (i) \\ ' Department of Architecture, College of Engineering and Environmental Studies, Olabisi Onabanjo University, Ogun State, Nigeria \\ 2 Department of Epidemiology and Medical Statistics, College of Medicine, University of Ibadan, Nigeria \\ ${ }^{3}$ Department of Architecture, School of Environmental Technology, Federal University of Technology, Akure, Nigeria \\ 'E mail: dipeolu.adedotun@oovagoiwoye.edu.ng, 2E mail: onojamatthew@yahoo.co.uk,32E mail: joechrisdamiro@yahoo.com
}

\begin{tabular}{|l|}
\hline A R T I C L E I N F O: \\
\hline Article history: \\
Received 26 March 2019 \\
Accepted 15 June 2019 \\
Available online 29 August \\
2019 \\
\hline \\
Keywords: \\
-Environmental sustainability \\
challenges; \\
- Green infrastructure; \\
- Perceived health; \\
- Mitigating Environmental \\
challenges; \\
-Urban Communities.
\end{tabular}

This work is licensed under a Creative Commons Attribution NonCommercial - NoDerivs 4.0. "CC-BY-NC-ND" (c) $(1) \ominus$ BY NO ND

This article is published with Open Access at www.ijcua.com

\section{A B S T R A C T}

Green Infrastructure (GI) facilities have the capacity to enhance health and mitigate Environmental Sustainability Challenges (ESC). However, the extent of the mitigation and health benefits is unclear in developing countries. This study examined the impact of GI on ESC and Perceived Health (PH) of urban residents in Lagos Metropolis, Nigeria. Multi-stage sampling technique was used to select 1858 residents of Lagos Metropolis who completed semi-structured questionnaires. Descriptive statistics and chi-square test were used to explore data distributions and assess the association of the availability of GI with resident's $P H$ and ESC. Odds ratio with 95\% confidence interval (OR;95\%CI) were estimated for good health and ESC mitigation. Participants were mostly men (58.9\%) and younger than 50 years old (86.3\%). Good health (20.5\%) and high mitigation of ESC (collection and disposal of waste-52.7\% and official development assistance63.9\%) were reported where GI is mostly available. Participants were more likely to report good health (OR:1.40; 95\%CI:1.02-1.92) and high mitigation of ESC [water quality (OR:1.42; 95\%CI:1.12-1.81) passenger transport mode (OR:1.41; 95\%CI:1.06-1.89)] where GI are mostly available. Availability of Green infrastructure is supporting health and mitigating environmental sustainability challenges in the study area. Green infrastructure should be provided in urban areas where environmental sustainability is under threat.

\section{JOURNAL OF CONTEMPORARY URBAN AFFAIRS (2020), 4(1), 33-46.} https://doi.org/10.25034/ijcua.2020.v4n1-4

www.ijcua.com

Copyright (C) 2019 Journal of Contemporary Urban Affairs. All rights reserved.

\section{Introduction}

Urban sprawl, rapid depletion of forest areas and urban degradation among others have constituted daunting challenges to the environment in recent time. In addition, other more widespread land-uses, such as agriculture and industrial activities, have split up valuable landscapes, intensified the use of more energy, fertilizer and water (Gutman, 2007; Jongman, 2003). 
This uncurbed urbanisation and shift from forest systems to mechanized and grey infrastructure laden environment has resulted in the reduction of species' richness and weakened the capacity of ecosystems for natural food production, rejuvenation of human health, maintenance of aquatic and terrestrial resources, regulate microclimate and air quality in the built environment (Tzoulas et al., 2007; Ward Thompson, 2011). To ameliorate some of these negative consequences of urbanization, strategies of green infrastructure was proposed as a solution to tackle environmental sustainability and human wellbeing especially in rapidly developing urban centres (Pakzad \& Osmond, 2016).

Green infrastructure (GI) is a network of multifunctional green space facilities that can increase connectivity between existing natural areas, encourage ecological coherence while improving the quality of life and well-being. Various research efforts in the built environment are currently geared towards improving ecosystem services through the development of Gl (Maes et al., 2015; Wolch et al., 2014), mostly as a strategy to cope with divers' environmental sustainability challenges. However, despite the numerous benefits of the green infrastructure, rapid population growth and changes in land uses have put these facilities under pressure. This poses questions regarding the quantity and types of $\mathrm{Gl}$ within a neighbourhood/community which are required to mitigate environmental sustainability challenges and enhance human health (Maes et al., 2015; Ward Thompson et al., 2016).

Specifically, empirical evidence shows that activities or living around green spaces promote physical health, psychological well-being, and the general public health of users (Maes et al., 2015; Takano et al., 2002; Wolch et al., 2014). Exposure to street trees, vegetation, green parks, gardens and other green spaces in urban areas have been connected with multiple health benefits, including reduced mortality, morbidity, mental fatigue, stress, and being more physically active (de Vries et al., 2003; Maas et al., 2008; Takano et al., 2002). Other environment-related benefits range from carbon sequestration, improved air and water quality, control of air pollution to urban heat island effect (Gómez-Muñoz et al., 2010).

In addition, studies from Australia (Humpel et al., 2004; Sugiyama et al., 2008) have identified that the quality of parks and landscapes in people's neighbourhood may contribute to more active lifestyles. Similar studies in the Netherlands demonstrated the benefits of green spaces near homes and their impact on stress and other patterns of morbidity associated with accessing distant green spaces (Maas et al., 2008; Maes et al., 2015). Apart from that, in a recent study among poor black and minority ethnic (BME) communities in the UK, the result suggested that health and recreation policy in the UK needs to create more opportunities and green facilities closer to BME communities in order to address the health inequalities experienced by these groups (Roe et al., 2016; Ward Thompson et al., 2016). Also, the availability of green spaces has been reported to enhance factors such as community cohesion and revitalization, improved housing conditions, neighbourhood pedestrian corridors, job availability, and more active youths in productive ventures (Jennings et al., 2017).

In general, green infrastructure can enhance health and mitigate environmental sustainability challenges (Jennings et al., 2017; Pakzad \& Osmond, 2016), but the aspect or dimension of the challenges, the extent of the mitigation and the effect that these will have on the health of urban residents in developing nations like Nigeria is unclear. The present study, therefore, examined the mitigating effects of $\mathrm{Gl}$ on selected environmental sustainability issues as well as the extent to which availability of $\mathrm{Gl}$ can enhance selfreported (perceived) health of urban residents in Lagos Nigeria.

\section{Methods}

\subsection{Participants and procedure}

A total of 1858 residents of Lagos State, Nigeria participated in this study. Participants were household heads or adult representative who can and were willing to provide the needed information. The sampling frame consisted of the 16 Local Government Areas (LGAs) in Lagos Metropolis. Selected LGAs were sub-divided into participants' neighbourhood defined by Enumeration areas (EAs). In each EA, households were systematically sampled from the list of numbered houses (households) until the required sample size allocated to the EA was reached. Consenting participants (household heads) were given the study questionnaire to complete in English language. Ethical approval (with the number MOE/OES/7250/52) for this study was obtained from the Lagos State Ministry of Environment Ethical Review Committee.

\subsection{Measures}

\section{Demographic information}

The study used a semi-structured questionnaire to collect data on participant's demography. Some of the information in the socio-demographic section of the questionnaire included gender, age, family size, marital status, household size, ethnic group, religion, occupation and rank in occupation/income level. 


\section{Availability of green infrastructure}

Preliminarily, participants were asked to specify if the green infrastructure is available in their neighbourhood, the approximate distance of the Gl facilities from their location, the type of $\mathrm{Gl}$ facilities available in their neighbourhood, reasons for visiting $\mathrm{Gl}$ sites and other related questions. To measure the availability of $\mathrm{Gl}$ in the neighbourhood; the literature was used to ascertain Gl types (Takano et al., 2002; Wolch et al., 2014) while the authors verified and documented all available Gl types in the study area. The available $G I$ in the study areas was grouped into four namely: Green spaces Gl, Tree features $\mathrm{Gl}$, Water features $\mathrm{Gl}$ and other spaces green infrastructure (consisting of green infrastructure facilities that cannot be categorised into any of the first three groups). Respondents were required to identify from the list of Gls in each group, all Gl facilities present in their neighbourhood.

\subsubsection{Health Benefits of Green Infrastructure (HBGI).}

The Health Benefits of Green Infrastructure (HBGI) was measured with the 12-item General Health Questionnaire (GHQ) developed by Goldberg. This (GHQ) instrument is a measure of the current mental health of participants. The GHQ has been previously used and validated in different nations, settings and cultures with very reliable results (Goldberg, 1992). Originally, the questionnaire was developed as a 60-item instrument but shortened versions of the questionnaire were later developed in response to some criticisms of the instrument. Such versions include GHQ-30, the GHQ-28, the GHQ-20, and the GHQ-12. The scale assessed the recent experiences of respondents on a particular symptom or behaviour. Each item is rated on a 4point scale $(1=$ less than usual, $2=$ no more than usual, $3=$ rather more than usual and $4=$ much more than usual) (Goldberg \& Williams, 1988). Examples of items include "been able to enjoy your normal day to day activities", "been able to concentrate on what you're doing" etc (Supplementary Table S1). In the present study, HBGI of the participants was measured in relation to whether or not they visit green infrastructure sites over the past 4 weeks. This selected duration (one-month) was considered sufficient to assess the health impacts of $\mathrm{Gl}$ on users based on recommendations of the British Heart Foundation National Centre (Milton et al., 2011). The 12-item GHQ has been used to assess health benefits in some settings with reasonable coefficient of reliability. In particular, Montazeri et al. (2003) reported an alpha coefficient of 0.87 for the GHQ scale in a study conducted in Iran, to assess the reliability and validity of the 12-item instrument.

\subsubsection{Environmental Sustainability Challenges}

Five facets measuring general environmental sustainability challenges were extracted from 27 facets of sustainability in a Report of the Joint UNECE/OECD/Eurostat working group on statistics for sustainable development. (UNECE/OECD/Eurostat Working Group on Statisti cs for Sustainable Development, 2008). The five facets were selected (for their relevance to the issues of environmental sustainability in the study setting) for the present study: Air Pollution (APL), Collection and Disposal of Waste (CDW), Water Quality (WQT), Passenger Transport Mode (PTM) and Official Development Assistance (ODA). Literature informed indicators or items relevant to the selected facets were used to measure sustainability challenges related to the facet (Bonaiuto et al., 2003; Müller et al., 2009; Sustainable Cities, 2012). Participants were required to show their agreement or disagreement to the 21 indicators (arranged within 5 facets) on a 7-point scale ranging from $1=$ strongly disagree to 7 = strongly agree. . Examples of indicators include "residents' health in this neighbourhood is threatened by air pollution" and "residents have access to clean drinkable water in this neighbourhood" (Supplementary Table S2).

\subsection{Data Management and Statistical Analysis Techniques}

Initially, frequency tables and cross tabulations were used to explore the distribution of the data and to enhance data cleaning/editing. Total raw score was calculated for each group of the $G$ I type [i.e Total Green spaces GI (TGRS), Total Tree Features GI (TTRF), Total Water Features GI (TWTF) and Total Other Spaces GI (TOTH)] as the sum of Gl facilities available in the area as indicated by the respondent. A Gl availability index was created using the total raw score as a percentage of the total GI facilities listed in the group. An overall Gl index was created for each respondent as a total of the group specific indices. The four groups of $\mathrm{Gl}$ availability indices (TGRS, TTRF, TWTF, TOTH), were categorized into 3 using the mean (M) and the standard deviation (SD) as follows: poorly available (if score < M+SD), moderately available (if $M-S D \leq$ score $\leq M+S D$ ), and mostly available (if score $>M+S D$ ). Similarly, the total score for the Health Benefits of $\mathrm{Gl}$ (HBGI) was categorized into 3 using the mean $(M)$ and the standard deviation (SD) as follows: poor health (if score < M+SD), fair health (if $M-S D \leq$ score $\leq M+S D$ ), and good health (if score > M+SD). Each facet of the Environmental Sustainability Challenges was also categorized into 3 using the mean (M) and the standard deviation (SD) as follows: low mitigation (if score < $M+S D$ ), 
moderately mitigation (if $M-S D \leq$ score $\leq M+S D$, and high mitigation if $\geq M+S D$ (Akpa \& Bamgboye, 2015; Issa \& Baiyewu, 2006).

The Chi-square test was used to assess whether the level of mitigation of the environmental sustainability challenges and good health benefit was associated with the availability of $\mathrm{Gl}$ facilities in the study area. The categories of the HBGl and each facet of the Environmental sustainability challenges were further dichotomized by combining the two upper categories to form only two outcomes. Binary logistic regression analysis (Adjusted and unadjusted analyses) was performed to estimate the odds ratio (OR) and their respective $95 \%$ Confidence Intervals (CI) for factors associated with $\mathrm{HBG}$ and each facet of environmental sustainability challenges. Covariates were included in the logistic regression depending on whether or not, they're significant in the bivariate (Chi-sqaures) test. All analyses were performed using IBM SPSS statistics version 20 with a significance level set at $5 \%$.

\section{RESULTS}

\subsection{Participants' Demography and Social Factors} More than half $(58.9 \%)$ of the participants are men while $41.1 \%$ of them are women. Participants are mostly younger than 50 years (86.3\%) and approximately $57 \%$ of them are married. Although most of them had completed tertiary education (59.9\%), $12 \%$ of them did not complete secondary education. About $43 \%$ of the participants were self-employed, $28.2 \%$ were employees of public/private organizations while $11.9 \%$ of them are unemployed (Table 1).

Table 1: Socio-demographics Characteristics of Respondents $(\mathrm{N}=1858)$

\begin{tabular}{|c|c|c|}
\hline Variables & Frequency & Percentage $(\%)$ \\
\hline \multicolumn{3}{|l|}{ Sex } \\
\hline Male & 1095 & 58.9 \\
\hline Female & 763 & 41.1 \\
\hline Total & 1858 & \\
\hline \multicolumn{3}{|l|}{ Current Age } \\
\hline$<30$ & 699 & 37.6 \\
\hline $30-49$ & 905 & 48.7 \\
\hline$>=50$ & 222 & 11.9 \\
\hline Not Reported & 32 & 1.7 \\
\hline Total & 1858 & \\
\hline \multicolumn{3}{|l|}{ Marital Status } \\
\hline Never Married & 711 & 38.3 \\
\hline Married & 1049 & 56.5 \\
\hline Formerly Married & 85 & 4.6 \\
\hline Not Reported & 13 & 0.7 \\
\hline Total & 1858 & \\
\hline \multicolumn{3}{|l|}{ Household Size } \\
\hline$<=4$ & 1063 & 57.2 \\
\hline$>4$ & 786 & 42.3 \\
\hline Not Reported & 9 & 0.5 \\
\hline Total & 1858 & \\
\hline \multicolumn{3}{|l|}{ Ethnic Group } \\
\hline Yoruba & 1298 & 69.9 \\
\hline Others & 559 & 30.1 \\
\hline Not Reported & 1 & 0.1 \\
\hline Total & 1858 & \\
\hline \multicolumn{3}{|l|}{ Highest Educational Qualification } \\
\hline Less than Secondary Education & 223 & 12.0 \\
\hline Secondary Education & 516 & 27.8 \\
\hline Tertiary Non Degree Education & 604 & 32.5 \\
\hline Tertiary Degree/Postgraduate Education & 510 & 27.4 \\
\hline Not Reported & 5 & 0.3 \\
\hline Total & 1858 & \\
\hline \multicolumn{3}{|l|}{ Occupation } \\
\hline Unemployed & 221 & 11.9 \\
\hline Self Employed & 797 & 42.9 \\
\hline Private/Public Employees & 524 & 28.2 \\
\hline Students \& Others & 316 & 17.0 \\
\hline Total & 1858 & \\
\hline \multicolumn{3}{|l|}{ Rank in Occupation/Income Level } \\
\hline Junior Staff & 478 & 25.7 \\
\hline Senior Staff & 275 & 14.8 \\
\hline Management Staff/Business Owners & 597 & 32.1 \\
\hline Not Reported & 508 & 27.3 \\
\hline Total & 1858 & \\
\hline
\end{tabular}


3.2. Factors associated with participants' perceived Health Benefits of Green Infrastructure

The proportion (20.5\%) of participants reporting perceived good health was significantly higher among those reporting that GI (overall) is mostly available in their neighbourhood. Also, the proportion of younger participants, aged $<50$ years $(85.1 \%)$ reporting perceived good health was significantly higher compared to participants aged $>50$ years $(14.8 \%)$. Participants who have completed tertiary education (58.8\%) reported perceived good health than those who did not have more than secondary school education (41.1\%). Poor health was mostly reported among participants who were not yet married (23.6\%) (Table 2).

Table 2: Factors associated with perceived Health Benefits of Green Infrastructure.

\begin{tabular}{|c|c|c|c|c|}
\hline & $\%$ with poor health & \% with fair health & $\%$ with good health & $\mathbf{P}$ \\
\hline Green Space GI & & & & 0.04 \\
\hline Poorly Available & $33(17.0)$ & $119(61.3)$ & $42(21.6)$ & \\
\hline Moderately Available & $206(22.7)$ & $559(61.5)$ & $144(15.8)$ & \\
\hline Mostly Available & $136(19.3)$ & $421(59.9)$ & $146(20.8)$ & \\
\hline Tree Feature GI & & & & 0.59 \\
\hline Poorly Available & $120(20.3)$ & $369(62.4)$ & $102(30.7)$ & \\
\hline Mostly Available & $255(21.0)$ & $730(60.1)$ & $230(69.3)$ & \\
\hline Water Feature GI & & & & 0.48 \\
\hline Moderately Available & $220(19.7)$ & $691(61.8)$ & $208(81.6)$ & \\
\hline Mostly Available & $57(22.9)$ & $145(58.2)$ & $47(18.4)$ & \\
\hline Other Spaces & & & & 0.22 \\
\hline Moderately Available & $204(21.6)$ & $580(61.4)$ & $160(48.2)$ & \\
\hline Mostly Available & $171(19.8)$ & $519(60.2)$ & $172(51.8)$ & \\
\hline Overall GI index & & & & 0.03 \\
\hline Poorly Available & $72(25.5)$ & $174(61.7)$ & $36(12.8)$ & \\
\hline Moderately Available & $131(20.1)$ & $403(61.9)$ & $117(18.0)$ & \\
\hline Mostly Available & $172(19.7)$ & $522(59.8)$ & $179(20.5)$ & \\
\hline Participants' Demography & & & & \\
\hline Sex & & & & 0.29 \\
\hline Male & $221(20.3)$ & $679(62.4)$ & $189(56.4)$ & \\
\hline Female & $168(22.1)$ & $447(58.7)$ & $146(43.6)$ & \\
\hline Current Age & & & & 0.01 \\
\hline$<30$ & $173(24.9)$ & $405(58.3)$ & $117(35.3)$ & \\
\hline $30-49$ & $164(18.2)$ & $572(63.5)$ & $165(49.8)$ & \\
\hline$>=50$ & $45(20.3)$ & $128(57.7)$ & $49(14.8)$ & \\
\hline Marital Status & & & & 0.009 \\
\hline Never Married & $166(23.6)$ & $410(58.3)$ & $127(38.4)$ & \\
\hline Married & $194(18.5)$ & $666(63.5)$ & $189(57.1)$ & \\
\hline Formerly Married & $27(31.8)$ & $43(50.6)$ & $15(4.5)$ & \\
\hline Household Size & & & & 0.34 \\
\hline$<=4$ & $233(22.0)$ & $644(60.8)$ & $182(54.5)$ & \\
\hline$>4$ & $156(19.9)$ & $475(60.7)$ & $152(45.5)$ & \\
\hline Ethnic Group & & & & 0.98 \\
\hline Yoruba & $270(20.9)$ & $787(61.0)$ & $234(69.9)$ & \\
\hline Others & $119(21.3)$ & $338(60.6)$ & $101(30.1)$ & \\
\hline Highest Educational Qualification & & & & 0.04 \\
\hline Less than Secondary & $41(18.5)$ & $128(57.7)$ & $53(15.9)$ & \\
\hline Secondary & $97(18.9)$ & $332(64.7)$ & $84(25.2)$ & \\
\hline Tertiary Non Degree & $138(22.9)$ & $348(57.7)$ & $117(35.1)$ & \\
\hline Tertiary Degree/Postgrad & $112(22.1)$ & $316(62.3)$ & $79(23.7)$ & \\
\hline Occupation & & & & 0.17 \\
\hline Unemployed & $59(26.8)$ & $119(54.1)$ & $42(12.5)$ & \\
\hline Self Employed & $149(18.7)$ & $506(63.6)$ & $140(41.8)$ & \\
\hline Private/Public Employees & $113(21.6)$ & $318(60.7)$ & $93(27.8)$ & \\
\hline Students \& Others & $68(21.9)$ & $183(58.8)$ & $60(17.9)$ & \\
\hline Rank in Occupation & & & & 0.32 \\
\hline Junior Staff & $92(19.3)$ & $296(62.1)$ & $89(38.0)$ & \\
\hline Senior Staff & $56(20.4)$ & $180(65.5)$ & $39(16.7)$ & \\
\hline Management Staff & $135(22.7)$ & $355(59.6)$ & $106(45.3)$ & \\
\hline
\end{tabular}

Note: percentages were calculated based on the row total of the the 3 categories of each facet of the Environmental Sustainability challenges GI-Green Infrastructure 
The results of the logistic regression analyses are presented as adjusted and unadjusted odds ratios (OR and aOR) with their respective $95 \%$ confidence intervals $(\mathrm{Cl})$ in Table 3 . The odds of reporting good health was higher for participants in areas where $\mathrm{Gl}$ (overall) are mostly available (OR: 1.40; 95\%Cl: 1.02-1.92). Similarly, the odds of reporting good health was higher among participants that are aged 30-49 years (OR: 1.49; 95\%Cl: 1.17-1.90) compared to participants that are less than 30 years of age. Being formerly married (OR: 0.47; 95\% Cl: 0.28-0.81) and aged 3049 years (OR: 1.39; $95 \% \mathrm{Cl}$ : 1.06-1.61) are independently associated with perceived health benefits of $\mathrm{Gl}$ (Table 3).

Table 3: Association of Green Infrastructure with Perceived Health benefit of GI

\begin{tabular}{|c|c|c|}
\hline Factors & $\begin{array}{c}\text { Odds of } \\
\text { Good Health } \\
(95 \% \text { CI })\end{array}$ & $\begin{array}{l}\text { Adjusted Odds of } \\
\text { Good Health } \\
\text { (95\% CI) }\end{array}$ \\
\hline \multicolumn{3}{|l|}{ Green Space GI } \\
\hline Poorly Available & - & - \\
\hline Moderately Available & $0.70(0.47-1.05)$ & $0.64(0.42-0.99)$ \\
\hline Mostly Available & $0.86(0.56-1.30)$ & $0.72(0.46-1.13)$ \\
\hline \multicolumn{3}{|l|}{ Overall GI Index } \\
\hline Poorly Available & & \\
\hline Moderately Available & $1.36(0.98-1.89)$ & $1.39(0.98-1.96)$ \\
\hline Mostly Available & $1.40(1.02-1.92)$ & $1.37(0.95-1.97)$ \\
\hline \multicolumn{3}{|l|}{ Current Age } \\
\hline$<30$ & - & \\
\hline $30-49$ & $1.49(1.17-1.90)$ & $1.39(1.06-1.61)$ \\
\hline$>=50$ & $1.30(0.90-1.89)$ & $1.24(0.83-1.85)$ \\
\hline \multicolumn{3}{|l|}{ Highest Educational Qualification } \\
\hline Less than Secondary & - & \\
\hline Secondary & $0.97(0.65-1.46)$ & $0.85(0.55-1.32)$ \\
\hline Tertiary Non Degree & $0.76(0.52-1.13)$ & $0.67(0.44-1.02)$ \\
\hline Tertiary Degree/Postgrad. & $0.80(0.54-1.19)$ & $0.67(0.44-1.03)$ \\
\hline \multicolumn{3}{|l|}{ Marital Status } \\
\hline Never Married & - & - \\
\hline Married & $1.36(1.08-1.72)$ & $1.19(0.91-1.55)$ \\
\hline Formerly Married & $0.66(0.41-1.08)$ & $0.47(0.28-0.81)$ \\
\hline
\end{tabular}

3.3. Adjusted Effects of Green Infrastructure on Environmental Sustainability Challenges and Participant's Health

The proportion reporting high mitigation of CDW (52.7\%) and ODA (63.9) challenges were significantly higher in areas were Gl (overall) are mostly available. High mitigation was equally reported for WQT (48.0\%) and ODA (65.0\%) challenges where tree features and green spaces $\mathrm{Gl}$ were respectively mostly available in the study area (Table 4). 
Table 4: Association between Availability of Gl and Environmental Sustainability challenges.

\begin{tabular}{|c|c|c|c|c|c|c|c|c|c|c|}
\hline \multirow[b]{2}{*}{$\begin{array}{l}\text { Green } \\
\text { Infrastructure }\end{array}$} & \multicolumn{2}{|c|}{ Air Pollution } & \multicolumn{2}{|c|}{$\begin{array}{c}\text { Collection and } \\
\text { Disposal of waste }\end{array}$} & \multicolumn{2}{|c|}{ Water Quality } & \multicolumn{2}{|c|}{$\begin{array}{c}\text { Passenger } \\
\text { Transport Mode } \\
\end{array}$} & \multicolumn{2}{|c|}{$\begin{array}{c}\text { Official } \\
\text { Development } \\
\text { Assistance }\end{array}$} \\
\hline & $\begin{array}{c}\text { \% reporting } \\
\text { High } \\
\text { mitigation } \\
\end{array}$ & $\boldsymbol{P}$ & $\begin{array}{c}\% \\
\text { reporting } \\
\text { High } \\
\text { mitigation } \\
\end{array}$ & $\boldsymbol{P}$ & $\begin{array}{c}\% \\
\text { reporting } \\
\text { High } \\
\text { mitigation } \\
\end{array}$ & $\boldsymbol{P}$ & $\begin{array}{c}\% \\
\text { reporting } \\
\text { High } \\
\text { mitigation } \\
\end{array}$ & $\boldsymbol{P}$ & $\begin{array}{c}\% \\
\text { reporting } \\
\text { High } \\
\text { mitigation } \\
\end{array}$ & $\boldsymbol{P}$ \\
\hline Green Space GI & & 0.16 & & 0.52 & & 0.80 & & 0.71 & & 0.03 \\
\hline $\begin{array}{r}\text { Poorly Available } \\
\text { Moderately }\end{array}$ & $97(50.0)$ & & $102(52.6)$ & & $91(46.9)$ & & $111(57.2)$ & & $114(58.8)$ & \\
\hline Available & $474(52.1)$ & & $470(51.6 .2)$ & & $437(48.0)$ & & $524(57.8)$ & & $520(57.4)$ & \\
\hline Mostly Available & $327(46.2)$ & & $384(54.2)$ & & $340(48.0)$ & & $387(55.0)$ & & $457(65.0)$ & \\
\hline Tree Feature GI & & 0.89 & & 0.25 & & 0.007 & & 0.78 & & 0.76 \\
\hline Poorly Available & $288(48.7)$ & & $327(55.3)$ & & $281(47.5)$ & & $333(56.6)$ & & $360(61.2)$ & \\
\hline Mostly Available & $610(50.0)$ & & $629(51.5)$ & & $587(48.1)$ & & $689(56.7)$ & & $731(60.2)$ & \\
\hline $\begin{array}{r}\text { Water Feature GI } \\
\text { Moderately }\end{array}$ & & 0.33 & & 0.33 & & 0.38 & & 0.99 & & 0.49 \\
\hline Available & $565(50.4)$ & & $583(52.0)$ & & $556(49.6)$ & & $647(58.1)$ & & $688(60.0)$ & \\
\hline Mostly Available & $119(48.0)$ & & $139(56.0)$ & & $112(45.2)$ & & $144(58.1)$ & & $159(64.1)$ & \\
\hline $\begin{array}{l}\text { Other Spaces } \\
\text { Moderately }\end{array}$ & & 0.77 & & 0.82 & & 0.21 & & 0.05 & & 0.30 \\
\hline Available & $473(49.9)$ & & $505(53.3)$ & & $468(49.4)$ & & $532(56.4)$ & & $563(59.7)$ & \\
\hline Mostly Available & $425(49.2)$ & & $451(52.2)$ & & $400(46.3)$ & & $490(57.0)$ & & $528(61.4)$ & \\
\hline Overall GI Index & & $<0.00$ & & & & & & & & \\
\hline $\begin{array}{r}\text { Poorly Available } \\
\text { Moderately }\end{array}$ & $158(55.8)$ & 1 & $130(45.9)$ & 0.02 & $142(50.2)$ & 0.45 & $172(61.2)$ & 0.23 & $161(57.3)$ & 0.02 \\
\hline Available & $323(49.5)$ & & $364(55.8)$ & & $312(47.9)$ & & $365(56.2)$ & & $372(57.3)$ & \\
\hline Mostly Available & $417(47.5)$ & & $462(52.7)$ & & $414(47.2)$ & & $485(55.6)$ & & $558(63.9)$ & \\
\hline
\end{tabular}

Note: percentages were calculated based on the row total of the 3 categories of each facet of the Environmental Sustainability Challenges

GI- Green Infrastructure

The results of the logistic regression further show that the odds of reporting high mitigation of water quality challenges were higher in areas where tree feature $\mathrm{Gl}$ are mostly available (OR: 1.42; $95 \% \mathrm{Cl}$ : 1.12-1.81) than where they are poorly available. Similarly, the odds of reporting high mitigation of challenges relating to passenger transport mode (transportation systems in the cities) was higher in neighbourhoods where other spaces $\mathrm{Gl}$ are mostly available (OR: $1.41 ; 95 \% \mathrm{Cl}: 1.06-1.89)$ than where they are moderately available (Table 5).

Table 5: Association of Green Infrastructure with Mitigation of Environmental Sustainability Challenge.

\begin{tabular}{ccccc}
$\begin{array}{c}\text { Odds of APL } \\
(95 \% \text { CI })\end{array}$ & $\begin{array}{c}\text { Odds of CDW } \\
(95 \% \text { CI })\end{array}$ & $\begin{array}{c}\text { Odds of WQT } \\
(95 \% \text { CI })\end{array}$ & $\begin{array}{c}\text { Odds of PTM } \\
(95 \% \text { CI })\end{array}$ & $\begin{array}{c}\text { Odds of ODA } \\
(95 \% \text { CI })\end{array}$ \\
\hline
\end{tabular}

\section{Green Space GI}

Poorly Available

Moderately Available

Mostly Available

\section{Tree Feature GI}

Poorly Available

Mostly Available

\section{Other Spaces}

Moderately Available

Overall GI

Mostly Available

Poorly Available

Moderately Available $\quad 0.44(0.29-0.68) \quad 1.08(0.75-1.54)$

Mostly Available

GI-Green Infrastructure, APL-Air Pollution, CDW-Collection and Disposal of waste, WQT-Water Quality, PTM-Passenger Transport Mode, ODA-Official Development Assistance 


\section{Discussions}

In this study, we report comparative results for the mitigating effects of $\mathrm{Gl}$ on selected environmental sustainability variables. We as well measured the extent of self-reported improvement on health of urban residents in Lagos Metropolis, in relation to the availability and access to green infrastructure. This study was premised on the literature (Jennings et al., 2017; Pakzad \& Osmond, 2016; Takano et al., 2002; Tzoulas et al., 2007; Ward Thompson et al., 2016) addressing links between access to $G$ facilities and health, particularly levels of reported good health in areas with green spaces and poor health induced by environmental sustainability challenges in urban centres. We explored potential mitigating effects of $\mathrm{Gl}$ on selected environmental sustainability issues as well as the extent to which availability of $\mathrm{Gl}$ can enhance the self-reported (perceived) health of urban residents in Lagos Nigeria.

First, we attempted to discover the sociodemographical factors associated with perceived health benefits of $\mathrm{Gl}$ facilities to isolate the independent capacity of $\mathrm{Gl}$ to impact health in the study area. A number of socio-demographic characteristics of the study participants were found to impact perceived health. For instance, the health benefit of $\mathrm{Gl}$ was reported mostly among younger participants and individuals who have completed tertiary education. In particular, more of the participants aged 30-49 years reported health benefit of Gl than any other age group. The links between socio-economic and demographic status and health are well ascertained (Dunn \& Hayes, 2000; Ross, 2000; Tzoulas et al., 2007). The 30-39 years age group consists of energetic and productive individuals compared to ages below or above the range. Consequently, participants within this age group have higher opportunity and possibly better emotional and social orientations to enjoy access to green infrastructure facilities in their neighbourhood compared to other individuals (Conedera et al., 2015). When controlled for age, sex, marital and socio-economic status, among older adults, past studies have provided evidence of a positive association between self-reported health (including longevity) and green space (de Vries et al., 2003; Takano et al., 2002).

Although we also observed that married participants and those who were formerly married reported health benefit of $\mathrm{Gl}$ than those who had never being married, we are unable to provide any immediate explanation for this. However, this result seems to suggest that people are more likely to benefit from their recreation/outdoor activities and access to $G$ facilities when they engage in such activities with other people than doing so alone. This finding is not alien to the literature as previous studies have reported evidence of the positive effect gained by nearby green spaces since this provides a place of contact between people and nature, increases the potential of meeting neighbours, and enables social wellbeing and social cohesion (Kuo et al., 1998; Wolch et al., 2014).

Furthermore, we found that the availability of street trees, green garden and parks, private garden or allotment, fountain, streams and other Gl facilities even when available moderately, have provided improved health to residents in the study area. The link between green spaces and health has been demonstrated in a number of studies. For instance, Payne et al. (1998) found that park users reported better general perceived health, higher levels of activity and improved ability to relax than non-users. Also, it has been shown in previous studies that those who visit green spaces at least once a month in winter reported significantly better health than those who refused to visit green spaces (Ward Thompson et al., 2016). Research has also been focussed on the effect of nearby trees and grass visible from apartment buildings on residents' effectiveness in facing major life problems including intra-family aggression by enhancing mental health (Kuo \& Sullivan, 2001; Tzoulas et al., 2007). However, it must be acknowledged that, even though these and other related studies were controlled for possible confounders, it is impossible to completely exclude the possibility of confounding factors; especially in relation to lifestyle that may inform health in neighbourhoods/communities near parks.

The impact of green infrastructure on environmental sustainability in the present setting is unclear. Participants in the present study reported high mitigation of environmental sustainability challenges (including collection and disposal of waste, poor water quality, passenger transport mode and official development assistance) in neighbourhoods where green infrastructure are moderately or mostly available. Previous studies in this area/direction confirmed that green infrastructure helps to maintain a healthy urban environment by using trees and other vegetations to screen and providing clean air, improving the urban climate and preserving the delicate balance of nature (Nowak et al., 2006; Tzoulas et al., 2007). It is therefore not surprising to found in the present study, that participants from areas where tree feature $\mathrm{Gl}$ are mostly available where $42 \%$ more likely to report high mitigation of water quality challenges than where they are poorly available. There are many evidences in the literature supporting our findings. Tavakol-Davani et al. (2016) reported that $\mathrm{Gl}$ facilities can reduce the amount of storm water entering urban 
drainage systems and thus improve water quality at urban centres. Many other studies have also evaluated the roles of various types of $\mathrm{Gl}$ on stormwater management, carbon sinks and emission controls (Liu et al., 2014, 2015). The roots of some trees have also been reported to serve as filters for underground water and thus improving the quality of drinking water. (Dong et al., 2017). Also, participants from areas where other spaces $\mathrm{Gl}$ (such as non green open spaces, non green Parks, schoolyards etc) are mostly available were $41 \%$ more likely to report high mitigation of challenges relating to passenger transport mode (transportation systems in the cities) than where they are moderately available. Similarly, recent studies have advocated for more street trees to create tree corridors where pedestrian can treck or cycle to various destination in the city (Singh, 2016; Thaiutsa et al., 2008). This measure has been suggested as a mitigation strategy against environmental challenges related to passenger transport mode or the transportation systems within the cities. The approach is seen as a sustainable transport mode that can eventually encourage sustainability in the cities.

\section{Strengths and limitations}

The present study is a strong and comprehensive contribution to the literature on the impact of $\mathrm{Gl}$ availability on health and environmental sustainability challenges from this study setting. The epidemiological nature of the study provides a great opportunity for targeted policy and intervention strategies. The major limitation of this study may be the self-administered nature of the

\section{References}

Akpa, O. M., \& Bamgboye, E. A. (2015). Correlates of the quality of life of adolescents in families affected by HIV/AIDS in Benue state, Nigeria. Vulnerable Children and Youth Studies, 10(3), 225-242. https://doi.org/10.1080/17450128.2015.1066914

Bonaiuto, M., Fornara, F., \& Bonnes, M. (2003). Indexes of perceived residential environment quality and neighbourhood attachment in urban environments: a confirmation study on the city of Rome. Landscape and Urban Planning, 65(1), 41-52. https://doi.org/10.1016/S0169-2046(02)00236-0

Conedera, M., Del Biaggio, A., Seeland, K., Moretti, M., \& Home, R. (2015). Residents' preferences and use of urban and peri-urban green spaces in a Swiss mountainous region of the Southern Alps. Urban Forestry \& Urban Greening, 14(1), 139-147. https://doi.org/10.1016/j.ufug.2015.01.003

de Vries, S., Verheij, R. A., Groenewegen, P. P., \& Spreeuwenberg, P. (2003). Natural EnvironmentsHealthy Environments? An Exploratory Analysis of the Relationship between Greenspace and Health. questionnaires which might have introduced some biases. Also, the GHQ-12 version of the General Health Questionnaire adopted for this study may equally provide a limitation to the robustness of our findings as we considered no criteria in our selection of the GHQ-12 among several other versions (GHQ-60, GHQ-30, GHQ-28, GHQ-20) of the scale. There were no local studies with which to immediately compare our findings, this may confer some contextual limitations on the conclusion of the present study.

\section{Conclusion}

Green infrastructure plays an integral role in supporting health in the urban communities studied, through the provision of environmental, social and economic benefits. There are also evidences that green infrastructure mitigates environmental sustainability challenges in the urban communities studied. In particular, green infrastructure improves the liveability of the built environment through maintenance of ecosystems, storm water reduction, improved air, water and habitat quality and enhances landscape connectivity for urban flora and fauna.

\section{Acknowledgment}

This research received no specific grant from any funding agency in the public, commercial, or notfor-profit sectors.

\section{Conflict of Interests}

The authors have no conflict of interest to report for this research.

Environment and Planning A: Economy and Space, 35(10), 1717-1731. https://doi.org/10.1068/a35111

Dong, X., Guo, H., \& Zeng, S. (2017). Enhancing future resilience in urban drainage system: Green versus grey infrastructure. Water Research, 124, 280-289. https://doi.org/10.1016/j.watres.2017.07.038

Dunn, J. R., \& Hayes, M. V. (2000). Social inequality, population health, and housing: a study of two Vancouver neighborhoods. Social Science \& Medicine, 51(4), 563-587. https://doi.org/10.1016/S0277-9536(99)00496-7

Goldberg, D. (1992). General Health Questionnaire (GHQ12). UK: Nfer-Nelson. http://www.sciepub.com/reference/128768

Goldberg, D. P., \& Williams, P. (1988). User's guide to the General Health Questionnaire. Windsor. https://www.scirp.org/(S(oyulxb452alnt1aej1nfow 45))/reference/ReferencesPapers.aspx?ReferenceI $\mathrm{D}=189650$ 
Gómez-Muñoz, V. M., Porta-Gándara, M. A., \& Fernández, J. L. (2010). Effect of tree shades in urban planning in hot-arid climatic regions. Landscape and Urban Planning, 94(3), 149-157. https://doi.org/10.1016/j.landurbplan.2009.09.002

Gutman, P. (2007). Ecosystem services: Foundations for a new rural-urban compact. Ecological Economics, 62(3-4), https://doi.org/10.1016/j.ecolecon.2007.02.027

Humpel, N., Owen, N., Iverson, D., Leslie, E., \& Bauman, A. (2004). Perceived environment attributes, residential location, and walking for particular purposes. American Journal of Preventive Medicine, 26(2), 119-125. https://doi.org/10.1016/j.amepre.2003.10.005

Issa, B. A., \& Baiyewu, O. (2006). Quality of Life of Patients with Diabetes Mellitus in a Nigerian Teaching Hospital. Hong Kong Journal of Psychiatry, 16(1). https://www.researchgate.net/profile/Baba_Issa/pu blication/237380920_Quality_of_Life_of_Patients with Diabetes_Mellitus_in_a Nigerian_Teaching _Hospital/links/02e7e52e-1f92 $\bar{b} 00811000000 /$ uali ty-of-Life-of-Patients-with-Diabetes-Mellitus-in-aNigerian-Teaching-Hospital.pdf

Jennings, V., Baptiste, A. K., Osborne Jelks, N. T., \& Skeete, R. (2017). Urban Green Space and the Pursuit of Health Equity in Parts of the United States. International Journal of Environmental Research and Public Health, 14(11). https://doi.org/10.3390/ijerph14111432

Jongman, R. H. G. (2003). Ecological networks and greenways in Europe: reasoning and concepts. Journal of Environmental Sciences, 15(2), 173-181. https://content.iospress.com/articles/journal-ofenvironmental-sciences/jes15-2-07

Kuo, F. E., Bacaicoa, M., \& Sullivan, W. C. (1998). Transforming Inner-City Landscapes: Trees, Sense of Safety, and Preference. Environment and Behavior, 30(1), 28-59. https://doi.org/10.1177/0013916598301002

Kuo, F. E., \& Sullivan, W. C. (2001). Aggression and Violence in the Inner City: Effects of Environment via Mental Fatigue. Environment and Behavior, $33(4)$, 543-571. https://doi.org/10.1177/00139160121973124

Liu, W., Chen, W., \& Peng, C. (2014). Assessing the effectiveness of green infrastructures on urban flooding reduction: A community scale study. Ecological Modelling, 291, 6-14. https://doi.org/10.1016/j.ecolmodel.2014.07.012

Liu, W., Chen, W., \& Peng, C. (2015). Influences of setting sizes and combination of green infrastructures on community's stormwater runoff reduction.
Ecological Modelling, 318, 236-244. https://doi.org/10.1016/j.ecolmodel.2014.11.007

Maas, J., Verheij, R. A., Spreeuwenberg, P., \& Groenewegen, P. P. (2008). Physical activity as a possible mechanism behind the relationship between green space and health: A multilevel analysis. BMC Public Health, 8(1), 206. https://doi.org/10.1186/1471-2458-8-206

Maes, J., Barbosa, A., Baranzelli, C., Zulian, G., Batista e Silva, F., Vandecasteele, I., Hiederer, R., Liquete, C., Paracchini, M. L., Mubareka, S., JacobsCrisioni, C., Castillo, C. P., \& Lavalle, C. (2015). More green infrastructure is required to maintain ecosystem services under current trends in land-use change in Europe. Landscape Ecology, 30(3), 517534. https://doi.org/10.1007/s10980-014-0083-2

Milton, K., Bull, F. C., \& Bauman, A. (2011). Reliability and validity testing of a single-item physical activity measure. British journal of sports medicine, 45(3), 203-208.

https://bjsm.bmj.com/content/45/3/203.short

Montazeri, A., Harirchi, A. M., Shariati, M., Garmaroudi, G., Ebadi, M., \& Fateh, A. (2003). The 12-item General Health Questionnaire (GHQ-12): translation and validation study of the Iranian version. Health and Quality of Life Outcomes, 1(1), 66. https://doi.org/10.1186/1477-7525-1-66

Müller, M. M., Kals, E., \& Pansa, R. (2009). Adolescents' emotional affinity toward nature: A cross-societal study. Journal of Developmental Processes, 4(1), 59-69.

https:/www.researchgate.net/profile/Markus_Muel ler39/publication/41845344_Adolescents'_Emotion al_Affinity_toward_Nature_A_Cross-

Societal_Study/links/58a2ef60aca272046ab50b40/ Adolescents-Emotional-Affinity-toward-Nature-ACross-Societal-Study.pdf

Nowak, D. J., Crane, D. E., \& Stevens, J. C. (2006). Air pollution removal by urban trees and shrubs in the United States. Urban Forestry \& Urban Greening, 4(3), 115-123. https://doi.org/10.1016/j.ufug.2006.01.007

Pakzad, P., \& Osmond, P. (2016). Developing a Sustainability Indicator Set for Measuring Green Infrastructure Performance. Procedia - Social and Behavioral Sciences, 216, 68-79. https://doi.org/10.1016/j.sbspro.2015.12.009

Payne, L., Orsega-Smith, B., Godbey, G., \& Roy, M. (1998). Local parks and the health of older adults. Parks \& Recreation (Ashburn), 33(10), 64-70. https://www.cabdirect.org/cabdirect/abstract/19991 800708

Roe, J., Aspinall, P. A., \& Ward Thompson, C. (2016). Understanding Relationships between Health, 
Ethnicity, Place and the Role of Urban Green Space in Deprived Urban Communities. International Journal of Environmental Research and Public Health, 13(7). https://doi.org/10.3390/ijerph13070681

Ross, C. E. (2000). Walking, exercising, and smoking: does neighborhood matter? Social Science \& Medicine, 51(2), 265-274. https://doi.org/10.1016/S02779536(99)00451-7

Singh, R. (2016). Factors Affecting Walkability of Neighborhoods. Procedia - Social and Behavioral Sciences, 216, 643-654. https://doi.org/10.1016/j.sbspro.2015.12.048

Sugiyama, T., Leslie, E., Giles-Corti, B., \& Owen, N. (2008). Associations of neighbourhood greenness with physical and mental health: do walking, social coherence and local social interaction explain the relationships? Journal of Epidemiology \& Community Health, 62(5), e9-e9. https://jech.bmj.com/content/62/5/e9.short

Takano, T., Nakamura, K., \& Watanabe, M. (2002). Urban residential environments and senior citizens' longevity in megacity areas: the importance of walkable green spaces. Journal of Epidemiology \& Community Health, 56(12), 913-918. https://jech.bmj.com/content/56/12/913.short

Tavakol-Davani, H., Burian, S. J., Devkota, J., \& Apul, D. (2016). Performance and cost-based comparison of green and gray infrastructure to control combined sewer overflows. Journal of Sustainable Water in the Built Environment, 2(2), 04015009. https://ascelibrary.org/doi/full/10.1061/JSWBAY.0 000805
Thaiutsa, B., Puangchit, L., Kjelgren, R., \& Arunpraparut, W. (2008). Urban green space, street tree and heritage large tree assessment in Bangkok, Thailand. Urban Forestry \& Urban Greening, 7(3), 219-229. https://doi.org/10.1016/j.ufug.2008.03.002

Tzoulas, K., Korpela, K., Venn, S., Yli-Pelkonen, V., Kaźmierczak, A., Niemela, J., \& James, P. (2007). Promoting ecosystem and human health in urban areas using Green Infrastructure: A literature review. Landscape and Urban Planning, 81(3), 167-178.

https://doi.org/10.1016/j.landurbplan.2007.02.001

UNECE/OECD/Eurostat Working Group on Statistics for S ustainable Development. (2008). MEASURING SUSTAINABLE DEVELOPMENT U NITED NATIONS.

Ward Thompson, C. (2011). Linking landscape and health: The recurring theme. Landscape and Urban Planning, 99(3), 187-195. https://doi.org/10.1016/j.landurbplan.2010.10.006

Ward Thompson, C., Aspinall, P., Roe, J., Robertson, L., \& Miller, D. (2016). Mitigating Stress and Supporting Health in Deprived Urban Communities: The Importance of Green Space and the Social Environment. International Journal of Environmental Research and Public Health, 13(4). https://doi.org/10.3390/ijerph13040440

Wolch, J. R., Byrne, J., \& Newell, J. P. (2014). Urban green space, public health, and environmental justice: The challenge of making cities 'just green enough'. Landscape and Urban Planning, 125, 234-244. https://doi.org/10.1016/j.landurbplan.2014.01.017

Dipeolu, A. A., Akpa, O. M. and Fadamiro, J. A. (2020). Mitigating Environmental Sustainability Challenges and Enhancing Health in Urban Communities: The Multi-functionality of Green Infrastructure. Journal of Contemporary Urban Affairs, 4(1), 33-46. https://doi.org/10.25034/ijcua.2020.v4n1-4 


\section{Supplementary Tables:}

Table S1: Health Benefits of Green Infrastructure

\begin{tabular}{lcccc}
\hline \multicolumn{1}{c}{ Item } & $\begin{array}{c}\text { Less than } \\
\text { usual } \\
(\%)\end{array}$ & $\begin{array}{c}\text { No more than } \\
\text { usual } \\
(\%)\end{array}$ & $\begin{array}{c}\text { Rather more } \\
\text { than usual } \\
(\%)\end{array}$ & $\begin{array}{c}\text { Much more } \\
\text { than usual } \\
(\%)\end{array}$ \\
\hline Been able to concentrate on what you're doing? & $238(12.9)$ & $339(18.3)$ & $671(36.3)$ & $602(32.5)$ \\
Lost much sleep over worry? & $922(49.8)$ & $480(25.9)$ & $306(16.5)$ & $142(7.6)$ \\
Felt that you are playing a useful part in things? & $160(8.6)$ & $354(19.1)$ & $791(42.8)$ & $545(29.5)$ \\
Felt capable of making decisions about things? & $141(7.6)$ & $273(14.8)$ & $779(42.1)$ & $655(35.5)$ \\
Felt constantly under strain? & $791(42.8)$ & $545(29.5)$ & $327(17.7)$ & $187(10.1)$ \\
Felt you couldn't overcome your difficulties? & $717(38.8)$ & $581(31.4)$ & $310(16.8)$ & $242(13.1)$ \\
Been able to enjoy your normal day to day & & & & \\
activities? & $214(11.6)$ & $256(13.8)$ & $821(44.4)$ & $559(30.1)$ \\
Been able to face up to your problems? & $188(10.2)$ & $305(16.5)$ & $764(41.3)$ & $593(32.0)$ \\
Been feeling unhappy or depressed? & $770(41.6)$ & $598(32.3)$ & $292(15.8)$ & $190(10.3)$ \\
Been losing confidence in yourself? & $790(42.7)$ & $669(36.2)$ & $229(12.4)$ & $162(8.7)$ \\
Been thinking of yourself as a worthless person? & $788(42.6)$ & $624(33.7)$ & $285(15.4)$ & $153(8.3)$ \\
Been feeling reasonably happy, all things & & & & \\
considered? & $160(8.6)$ & $242(13.1)$ & $736(39.8)$ & $713(38.4)$ \\
\hline
\end{tabular}

Table S2: General Environmental Sustainability

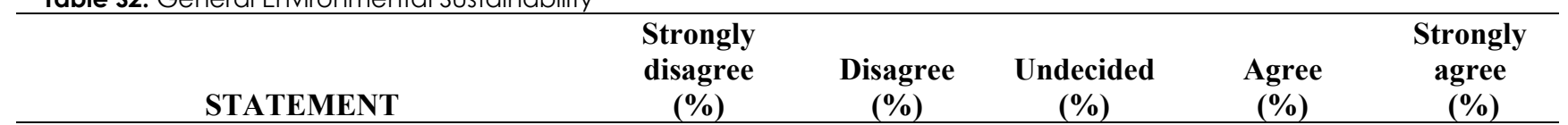

\section{Air pollution (APL)}

Residents' health is threatened by air pollution in this neighbourhood

The air in this neighbourhood is clean i.e free from automobiles, industry or farming pesticides and chemicals pollution.

The heavy traffic in this neighbourhood is very annoying

Air pollution caused by cars is very heavy in this neighbourhood

Air pollution caused by industry is very noticeable in this neighbourhood

Air pollution caused by pesticides and chemicals used in farming is very noticeable in this neighbourhood

$\begin{array}{lllll}417(22.5) & 581(31.3) & 314(16.9) & 319(17.2) & 223(12.0) \\ 570(30.7) & 377(20.3) & 381(20.5) & 396(21.3) & 130(7.0) \\ 292(15.7) & 733(39.5) & 360(19.4) & 288(15.5) & 182(9.8) \\ 333(18.0) & 739(39.8) & 336(18.1) & 269(14.5) & 178(9.6) \\ 191(10.3) & 557(30.1) & 430(23.2) & 401(21.7) & 271(14.6) \\ 123(6.6) & 285(15.4) & 476(25.6) & 494(26.6) & 478(25.8) \\ & & & & \\ 159(8.6) & 289(15.6) & 265(14.3) & 773(41.6) & 370(19.9) \\ 136(7.3) & 226(12.2) & 326(17.6) & 824(44.4) & 344(18.5) \\ 125(6.7) & 217(11.7) & 287(15.5) & 848(45.7) & 379(20.4) \\ & & & & \\ 138(7.4) & 205(11.0) & 289(15.6) & 834(44.9) & 390(21.0)\end{array}$

\section{Collection and disposal of waste (CDW)}

Residents in this neighbourhood avoid dirtying the environment

In this neighbourhood, residents find personal solution to their waste management

We have proper provision for waste disposal and management in this neighbourhood

Residents make good use of the neighbourhood waste collection effort effectively

\section{Water quality (WQT)}

Residents have access to clean drinkable water in this neighbourhood Available water in this neighbourhood is not clean enough for drinking

$\begin{array}{lllll}136(7.3) & 245(13.2) & 411(22.1) & 638(34.4) & 426(23.0) \\ 137(7.4) & 327(17.6) & 618(33.3) & 404(21.8) & 370(19.9)\end{array}$


Many residents have to make personal bore holes to get clean drinkable water in this neighbourhood

The underground water in this

neighbourhood is contaminated

\section{Passenger transport mode (PTM)}

The quality of public transportation is poor in this neighbourhood

In this neighbourhood, there are specific

and adequate provisions for cycling routes.

There are enough tree corridors under

which people can treck on sunny days

If you like cycling, this neighbourhood is

not suitable

Many residents in this neighbourhood support the use of public transport (such as public bus) instead of constantly driving their private cars

\section{Official development assistance}

\section{(Government support) (ODA)}

Government support for green

infrastructure facilities is noticeable in this neighbourhood

The Local Government in this area should strive to increase greenery in all neighbourhoods

Government to ensure sustainability as the future of all environmental projects Government should regularly orient citizens about benefits of green infrastructure

$\begin{array}{lllll}350(18.9) & 648(34.9) & 422(22.7) & 261(14.1) & 175(9.4) \\ 151(8.1) & 264(14.2) & 649(35.0) & 368(19.8) & 424(22.8)\end{array}$

$162(8.8) \quad 285(15.4) \quad 289(15.7) \quad 526(28.5) \quad 584(31.6)$

$663(35.9) \quad 539(29.2) \quad 341(18.5) \quad 221(12.0) \quad 82(4.4)$

$\begin{array}{lllll}706(38.2) & 469(25.4) & 352(19.1) & 223(12.1) & 96(5.2)\end{array}$

$\begin{array}{llll}720(39.0) & 693(37.5) & 217(11.8) & 128(6.9)\end{array}$

$\begin{array}{lllll}92(5.0) & 124(6.7) & 259(14.0) & 689(37.3) & 682(36.9)\end{array}$

$\begin{array}{lllll}464(25.1) & 611(33.1) & 472(25.6) & 200(10.8) & 99(5.4)\end{array}$

$\begin{array}{llll}41(2.2) & 115(6.2) & 223(12.1) & 898(48.6)\end{array}$

$\begin{array}{lllll}38(2.1) & 81(4.4) & 162(8.8) & 806(43.7) & 759(41.1)\end{array}$

$\begin{array}{lllll}42(2.3) & 57(3.1) & 133(7.2) & 703(38.1) & 911(49.3)\end{array}$


www.ijcua.com

This page is intentionally left blank. 